\title{
A Descriptive Overview of Pronunciation Instruction in Iranian High Schools
}

\author{
Hesamoddin Shahriari $^{1} \&$ Beheshteh Shakhsi Dastgahian ${ }^{2}$ \\ ${ }^{1}$ Department of English Language and Literature, Ferdowsi University of Mashhad, Mashhad, Iran \\ ${ }^{2}$ Corresponding Author, Ferdowsi University of Mashhad, International Branch, Mashhad, Iran \\ Correspondence: Beheshteh Shakhsi Dastgahian, Ferdowsi University of Mashhad, International Branch, \\ Mashhad, Iran. E-mail: b.dastgahian@yahoo.com
}

\author{
Received: February 3, 2014 Accepted: March 4, 2014 Online Published: March 26, 2014 \\ doi:10.5539/ijel.v4n2p1 \\ URL: http://dx.doi.org/10.5539/ijel.v4n2p1
}

\begin{abstract}
The emergence of English as an international language has undoubtedly influenced the way the language is taught all around the world. Among all the skills and components of English, pronunciation has perhaps been the one most highly affected by this trend. In a country, such as Iran, where learners come from a variety of dialectical backgrounds, English is taught using the same national syllabus and textbooks in all parts of the country. Hence, an investigation into the most prevalent approaches to pronunciation instruction can shed light on the techniques employed by teachers to overcome the difficulties brought about by linguistic diversity. The present study seeks to fulfill this aim by developing and administering a questionnaire among 130 teachers in the Iranian public education system, asking them about the most common approaches and techniques they use for teaching pronunciation in their classrooms. An exploratory factor analysis of the responses revealed that four major sets of techniques were commonly employed by the teachers surveyed in this study. Comparisons drawn between the participants revealed some important differences based on the teachers' age, gender, years of experience and educational background. These differences are discussed in light of the multilingual context of education in Iran.
\end{abstract}

Keywords: second/foreign language, pronunciation instruction, teacher preference

\section{Introduction}

\subsection{Definitions of Pronunciation}

According to the Longman Dictionary of Applied linguistics, pronunciation is defined as "the way sounds are perceived by the hearer" (Richards, Platt, \& Weber, 1985). It is a complicated mechanism taking place in an individual's working memory during oral production and is of great importance to most language instructors (Nation \& Newton, 2009). However, a great amount of disparity can be found among the various definitions in the existing body of literature. For instance, Zemanova (2007) provides a definition that is, despite its foundational overlap, different in focus from the one cited above. He claims that for every particular language, pronunciation is defined as the accepted standards of sound rhythm seen in different words.

\subsection{Background}

Of all skills and components involved in teaching a foreign language, pronunciation has perhaps received the least amount of attention (Celce-Murcia, Brinton, \& Goodwin, 1996; Kelly, 1969). Compared to other skills and components, fewer studies have been conducted into the field of pronunciation (Krashen, 1982; Derwing \& Munro, 2005), and many believe that this component has remained "marginalized" in the field of applied linguistics (Derwing \& Munro, 2005, p. 378). Indeed, this is why it has sometimes been referred to as the Cinderella of language teaching (Kelly, 1969). While some scholars emphasize the importance of this component (Nation \& Newton, 2009), others have questioned the effectiveness of teaching pronunciation, especially in the EFL classroom (Purcell \& Suter, 1980). The former camp emphasizes the role of pronunciation in effective communication and comprehensibility, alongside its high social value and link to prestige (Gelvanovsky, 2002); on the other hand, those against teaching pronunciation base their reasoning upon biological restrictions (especially among adult learners), as well as inhibiting sociological and personality factors (Richards \& Renandya, 2002). Despite the ongoing debate among these groups, most language teaching experts would agree 
that comprehensible pronunciation is a common feature among all successful language learners, and intelligible/comprehensible pronunciation is deemed to be necessary for each and every user of the target language (Zemanova, 2007). Furthermore, even if pronunciation is not desired for its own sake, many scholars believe that a certain level of pronunciation instruction is necessary because achievements in pronunciation often help learners to increase their expertise in other skills (e.g., Celce-Murcia, Brinton, \& Goodwin, 1996; Jenkins, 1998; Levis \& Grant, 2003; Morley, 1991; Zemanova, 2007). For instance, Kellerman (1990) points out that by mastering the phonology of the target language, learners will be able to improve their listening skill simultaneously. He resulted that despite the lack of unanimity regarding its importance, almost all language teaching experts would agree that pronunciation ought to be included in all EFL/ESL textbooks and curriculums.

In the process of teaching pronunciation, teachers are believed to have the first and foremost role. Not only do teachers establish models of correct pronunciation for their learners, but they additionally facilitate the learning and articulation of new sounds through the implementation of different techniques and exercises (Nation \& Newton, 2009). Teachers can greatly ease the mastery of second language phonology by discovering the reasons underlying pronunciation difficulties and trying to remove them in a reasonable way (Nation \& Newton, 2009). Morley (1991) refers to English language teachers as "pronunciation coach(es)" who have an essential role in "speech production (i.e., the micro-level) and speech performance (i.e., the macro-level)" (p. 507). Knowing which techniques to use in the face of each learning difficulty is another prominent feature of successful teachers of pronunciation (Nation \& Newton, 2009). For example, Hammerly (1982) believes that some teachers instruct new sounds using words that are known by students, in order to reduce possible problems in the process of learning, since if the sounds are taught and introduced in unknown words, it would most likely result in greater difficulties on the learners' behalf. Teachers can also play an important part in lowering their learners' affective barriers and easing the psychological concerns that most learners face when learning the sound system of a second/foreign language (Hammerly, 1982). Nation and Newton (2009) believe that teachers can guide those learners who hold negative opinions of themselves when pronouncing new sounds by improving their attitudes towards the new language in which they are engaged. Sometimes, teachers have to play the role of the psychologist in order to find the causes of nervousness brought about in learners dealing with the sound system of another language, therefore, the success rate of learning correct L2 pronunciation greatly hinges on the skill and proficiency of the teacher (Morley, 1991).

Language researchers and practitioners have introduced different techniques for teaching pronunciation (Nation \& Newton, 2009). The selection of the most suitable technique for any teaching context is dependent on a number of related variables, some of which include: learners' age, their first language, their proficiency level, their attitudes, and teaching and learning conditions (Nation \& Newton, 2009). There are two general approaches for teaching pronunciation: (a) "an intuitive-imitative approach" which deals with the learner's ability to listen and imitate the sounds of a target language without having clear knowledge about the sound system of the target language; and (b) "an analytic-linguistic approach" which in addition to listening and imitation, focuses on producing the correct sounds in the target language (Celce-Murcia, Brinton, \& Goodwin, 1996, p. 2). In this regard, Celce-Murcia, Brinton, and Goodwin (1996) have introduced some techniques for teaching pronunciation commonly used by teachers:

(a) Listening and imitating technique, which involves precise listening and imitation based on the teachers' model.

(b) Phonetic training, which deals with the usage of "articulatory descriptions, articulatory diagrams, and a phonetic alphabet".

(c) Minimal pair drills, through which students differentiate uncoordinated sounds from coordinated ones in the target language.

Another classification of techniques in teaching pronunciation has been provided by Murphy (2003) who categorized "three primary orientations" for teaching pronunciation in the ESL/EFL setting: (a) listening and imitating orientation, which engages learners with an automatic reproduction of sounds in the target language; (b) analyzing the sounds in order to practice vowels and consonant sounds; and (c) using the sounds communicatively, which is said to provide some opportunities for learners to apply their experiences with their teacher's support and guidance (pp. 113-114). The choice of techniques and manners of instruction depends on learner- and context-related variables, and varies from one learning context to another (Derwing \& Munro, 2005; Stuparyk, 1996; Usher, 1995). A number of studies have attempted to describe the status of pronunciation instruction in different countries. Some of these studies have described the status quo by seeking the opinions of teachers and planners; others, on the other hand, have looked at the opinions and attitudes of the learners. For 
instance, Breitkreutz, Derwing, and Rossiter (2001) distributed surveys among the teachers and program coordinators of Canadian ESL programs. The results of this study underscored differences of opinion regarding the significance of teaching pronunciation to ESL learners at various levels of proficiency. In another study, Kang (2009) investigated the attitudes of 238 adult ESL learners from New Zealand toward pronunciation instruction. Similarly, researchers have also conducted studies into pronunciation instruction in Iran. Hosseini Fatemi and Shahriari Ahmadi (2010) investigated the preferences of 112 Iranian EFL learners from different proficiency backgrounds towards various English accents. The authors of this study concluded that language teachers should consider the learners' needs and personal preferences when deciding on the process of pronunciation instruction. Hayati (2010) also administered a 38-item questionnaire to 230 Iranian English teachers to explore their perceived complications of teaching pronunciation. The result of his study highlighted concerns regarding the insufficiency of time allocated to pronunciation practice and the problems which exist in the high school textbooks.

The present study similarly intends to describe the status of pronunciation instruction in the Iran high school education system. However, unlike the studies cited above, the purpose is not to seek the opinions of teachers and learners. Instead, this study strives to determine the most common practices and techniques employed in the classrooms. Such a descriptive account could greatly assist the diagnosis of problems within the system, and could help determine whether the practiced techniques and exercises match the teaching and learning context and the variant characteristics of the learners who come from a range of dialectical backgrounds.

\section{Method}

\subsection{Participants}

One hundred and twenty Iranian English foreign language teachers (35 males and 85 females) voluntarily participated in this research. The youngest and oldest participants in this study were 22 and 52 years old, respectively; and the mean age of the participants was 35 . teachers varied in the degrees they held, ranging from bachelor to master, in majors such as English Literature, Translation Studies and English Language Teaching. Another difference between the teachers who participated in this study was in their years of experience teaching English at high schools. All teachers were grouped based on their experience into three distinct categories of Low, Mid and High experience levels. Finally, all teachers spoke Persian as their mother tongue; and since the Iranian Ministry of Education has no foreign recruit system, the participants of this study could be said to represent the whole body of practicing teachers in Iranian high schools.

\subsection{Instrument}

To collect the required data, a 20-item questionnaire was designed, piloted, and subsequently administered among 120 male and female high school English teachers. The questionnaire was designed to elicit responses from teachers regarding their standard practice in teaching pronunciation at high school. The questionnaire consists of two sections. In the first section, demographic information (including age, gender, major, degree, years of teaching experience, name, and district of high school where the respondent is currently employed) is collected. In the second section of the questionnaire, 20 statements regarding the practice of teaching pronunciation was listed. These statements were designed based on the proposed techniques for teaching pronunciation in Nation and Newton (2009). This book covers the most widely-practiced techniques that have been researched and recommended by experts of the field. The use of the aforementioned textbook as a guide precludes the inclusion of non-standard or idiosyncratic techniques into the final questionnaire, adding to the validity of the instrument. The respondents were required to mark the frequency with which they adopted each of the techniques on a four-point Likert scale. The pretext for using a four-point scale was that there was no mid-point, and it would hence elicit responses that are more interpretable. The options on the scale were always, often, sometime, and never. Despite the fact that all participants in the study were EFL teachers, in order to ensure the participants' thorough understanding of the items, the questionnaire was designed in Persian. Prior to the final administration of the questionnaire, it underwent a pilot stage, in which the questionnaire was given to three experts in the field who were asked to point out anything they found to be ambiguous or difficult to understand.

\subsection{Procedures}

The pronunciation questionnaire was administered to volunteer male and female high school English teachers after receiving their verbal approval. All respondents were briefed on necessary details such as the format of the questionnaire and how responses should be provided. The participants were informed that their responses would be anonymous and would only be used for the study at hand. This point was specifically emphasized so as not to be taken as a mistake with other instruments of professional evaluation. One of the researchers was present 
during the administration and provided answers in Persian to questions the participants faced. Finally, prior to the final analysis, questionnaires with internally inconsistent responses were excluded from the study.

\subsection{Data Analysis}

In order to address the research questions of the present study, the Statistical Package for Social Sciences (SPSS) was used to compute descriptive and inferential statistics. For the first research question, descriptive statistics including mean, minimum, and maximum were calculated. As for the second research question, Exploratory Factor Analysis (EFA) with varimax rotation was employed. The independent sample T-test was used for the third and fourth research questions; and finally, for the fifth research question, one-way analysis of variance (ANOVA) was the statistical test of choice.

\section{Results}

Descriptive statistics were used to see which of these 20 different methods of teaching pronunciation was used more frequently by the teachers who participated in this study. As can be seen in Table 1, Q-1 (To teach accurate pronunciation, I read the words in the classroom, and then I want students to repeat them) obtained the highest mean score, and Q-20 (For assessment, I use an oral assessment method) ranked second and was the second most commonly chosen practice in the survey. This finding shows that oral repetition is apparently the most popular method for teaching pronunciation among Iranian high school teachers. Also descriptive statistics represented that among three surveyed assessment techniques (multiple choice, dictation, and oral assessment) the third has the highest rate of popularity among Iranian high school teachers. Table 1 shows the descriptive statistics for the responses provided to each of the 20 items in the questionnaire.

Table 1. Descriptive Statistics on elicited responses to questionnaire items

\begin{tabular}{lllll}
\hline & N & Minimum & Maximum & Mean \\
\hline Q1 & $\mathbf{1 2 0}$ & $\mathbf{2 . 0 0}$ & $\mathbf{4 . 0 0}$ & $\mathbf{3 . 6 1 6 7}$ \\
Q2 & 120 & 1.00 & 4.00 & 2.6500 \\
Q3 & 120 & 1.00 & 4.00 & 2.5250 \\
Q4 & 120 & 1.00 & 4.00 & 2.5417 \\
Q5 & 120 & 1.00 & 4.00 & 2.6000 \\
Q6 & 120 & 1.00 & 4.00 & 3.0167 \\
Q7 & 120 & 1.00 & 4.00 & 2.2417 \\
Q8 & 120 & 1.00 & 4.00 & 1.9083 \\
Q9 & 120 & 1.00 & 4.00 & 2.5750 \\
Q10 & 120 & 1.00 & 4.00 & 2.6333 \\
Q11 & 120 & 1.00 & 4.00 & 1.8083 \\
Q12 & 120 & 2.00 & 4.00 & 3.5500 \\
Q13 & 120 & 1.00 & 4.00 & 2.9250 \\
Q14 & 120 & 1.00 & 4.00 & 2.9000 \\
Q15 & 120 & 1.00 & 4.00 & 2.9750 \\
Q16 & 120 & 1.00 & 4.00 & 3.1417 \\
Q17 & 120 & 1.00 & 4.00 & 2.3500 \\
Q18 & 120 & 1.00 & 4.00 & 2.5417 \\
Q19 & 120 & 1.00 & 4.00 & 2.1583 \\
Q20 & $\mathbf{1 2 0}$ & $\mathbf{1 . 0 0}$ & $\mathbf{4 . 0 0}$ & $\mathbf{3 . 3 5 0 0}$ \\
\hline
\end{tabular}

Imitation is perhaps the most intuitive technique for teaching the pronunciation of a foreign language. The results of this study also show that Iranian high school teachers make greater use of this technique in their classrooms. Other studies have also shown that oral repetition and mimicry are the most effective methods practiced by 
language teachers in general (Trofimovich \& Gatbonton, 2006). By analyzing the most commonly-used techniques for teaching second language pronunciation, Silveira (2002) concludes that one of the most useful techniques applied is "imitating a model through repetition" (p. 95). Therefore, the results of the present survey show that Iranian high school teachers also generally fall back on what is believed to be the most intuitive and effective method for teaching pronunciation. Furthermore, the oral assessment technique, which was found to be the second most commonly-used technique by Iranian high school teachers in their classrooms, has been advocated by language teaching specialists (e.g., Nakatani, 2002, 2005, 2006; Politzer \& McGroarty, 1985). This technique is frequently used by language teachers for assessing students' oral performance in general and pronunciation, in particular (Kim, 2009).

In order to examine the construct validity of the scale used for data collection in this study, exploratory factor analysis with principal component analysis and varimax rotation was utilized. Factor loadings above .35 were retained, and cross-loadings were removed. Results of the EFA are shown in table 2.

As can be seen in table 2, four factors were extracted after using EFA. The first factor, which included 8 items, was named teaching pronunciation with a focus on oral practice. The second factor included seven items and was called teaching pronunciation using instructional materials. The third factor was called teaching pronunciation using reference materials (e.g., dictionaries) and included three items. Finally, the fourth factor included two items and was called teaching pronunciation with a focus on articulation details. Also, to examine the internal consistency of the subscales, Cronbach's alpha was used. Cronbach's alpha calculated for these subscales is shown in table 3 . All the subscales enjoy a reasonable amount of reliability.

In order to examine whether there is a significant difference between the techniques used by males and females in teaching pronunciation, an independent samples T-test was used. The descriptive statistics for the two groups are shown in tables 4 , and table 5 shows the results of the independent samples T-test.

Table 2. Results of exploratory factor analysis

\begin{tabular}{|c|c|c|c|c|}
\hline \multicolumn{5}{|c|}{ Rotated Component Matrix } \\
\hline & \multicolumn{4}{|c|}{ Component } \\
\hline & 1 & 2 & 3 & 4 \\
\hline Q12 & .742 & & & \\
\hline Q20 & .716 & & & \\
\hline Q13 & .671 & & & \\
\hline Q6 & .435 & & & \\
\hline Q16 & .744 & & & \\
\hline Q9 & .727 & & & \\
\hline Q15 & .632 & & & \\
\hline Q1 & .443 & & & \\
\hline Q19 & & .709 & & \\
\hline Q17 & & .652 & & \\
\hline Q8 & & .607 & & \\
\hline Q11 & & .603 & & \\
\hline Q14 & & .726 & & \\
\hline Q18 & & .616 & & \\
\hline Q7 & & .436 & & \\
\hline Q2 & & & .786 & \\
\hline Q3 & & & .769 & \\
\hline Q10 & & & .428 & \\
\hline Q5 & & & & .815 \\
\hline Q4 & & & & .781 \\
\hline
\end{tabular}


Table 3. Results of Cronbach's alpha test for the internal consistency of instrument

\begin{tabular}{lll}
\hline Subscale & Cronbach's alpha & N of items \\
\hline oral practice & .74 & 8 \\
Materials & .70 & 7 \\
Dictionary & .68 & 3 \\
place of articulation & .71 & 2 \\
\hline
\end{tabular}

As can be seen in Table 5, there is a significant difference between male and female teachers in their use of oral techniques $(\mathrm{t}=1.99, \mathrm{df}=118, \mathrm{p}<.05$, effect size $=.20$, small effect $)$ and materials $(\mathrm{t}=1.98, \mathrm{df}=118, \mathrm{p}<.05$, effect size $=.20$, small effect) in teaching pronunciation. As the mean scores indicate, male teachers have reported greater use of both oral techniques $(M=15.94)$ and use of materials $(M=20.20)$, compared to their female counterparts $\left(\mathrm{M}_{\text {oral }}=14.40, \mathrm{M}_{\text {material }}=18.63\right)$. The oral techniques included in the questionnaire included oral repetition, paying attention to the pronunciation of sounds, drawing comparisons between L1 and L2 sounds, giving importance to learners' correct pronunciation, practicing the sounds in peer groups, elaborating different sounds in L1 and L2, teaching L2 sound in more simple words, and oral assessment. A possible reason why female teachers were less inclined to make use of oral techniques may be the demanding nature of these techniques. In a study carried out by Smith et al. (1998) on voice-related problems among teachers, it was found that female teachers reported more problems with their voice compared to males and these problems affected their teaching. This problem is even more evident in Iranian high schools, where classes consist of sometimes up to 50 students. In such instances, techniques such as oral repetition place tremendous pressure on teachers, especially female teachers who have been reported to have more sensitive vocal cords.

Table 4. Descriptive statistics for male and female teachers' use of techniques

\begin{tabular}{llllll}
\hline Gender & & $\mathrm{N}$ & Mean & Std. Deviation & Std. Error Mean \\
\hline Oral & Male & 35 & 15.94 & 4.33 & .73 \\
& Female & 85 & 14.40 & 3.68 & .39 \\
\hline Materials & Male & 35 & 20.20 & 4.12 & .69 \\
& Female & 85 & 18.63 & 4.02 & .43 \\
\hline References & Male & 35 & 7.28 & 1.87 & .31 \\
& Female & 85 & 7.15 & 2.09 & .22 \\
\hline Art. Details & Male & 35 & 4.60 & 1.80 & .30 \\
& Female & 85 & 4.96 & 1.70 & .18 \\
\hline
\end{tabular}

A similar independent samples T-test was employed to determine whether there was a difference between teachers with various levels of education (e.g., bachelor's and master's degrees) in terms of their preferred techniques for teaching pronunciation in the high school classroom. Tables 6 and 7 show the descriptive statistics for the two groups and the results of the independent samples T-test drawing comparisons between them. 
Table 5. Results of independent samples t-test comparing male and female teachers

\begin{tabular}{lllllll}
\hline Independent Samples t Test & \multicolumn{7}{l}{} \\
\hline & & \multicolumn{2}{c}{$\begin{array}{c}\text { Levene's Test for Equality of } \\
\text { Variances }\end{array}$} & \multicolumn{2}{c}{ T-test for Equality of Means } \\
\cline { 3 - 8 } & & F & Sig. & $\mathrm{t}$ & $\mathrm{df}$ & Sig. (2-tailed) \\
\hline Oral & Equal variances assumed & .94 & .33 & 1.99 & 118 & .04 \\
& Equal variances not assumed & & & 1.85 & 55.25 & .07 \\
\hline Materials & Equal variances assumed & .03 & .86 & 1.98 & 118 & .05 \\
& Equal variances not assumed & & & 1.90 & 62.04 & .06 \\
\hline Dictionary & Equal variances assumed & 1.36 & .24 & .32 & 118 & .74 \\
& Equal variances not assumed & & & .34 & 70.36 & .73 \\
\hline Place & Equal variances assumed & .33 & .56 & -1.04 & 118 & .29 \\
& Equal variances not assumed & & & -1.02 & 60.22 & .31 \\
\hline
\end{tabular}

Table 6. Descriptive statistics for use of techniques by teachers with bachelor's and master's degrees

\begin{tabular}{llllll}
\hline Group Statistics & & & & & \\
\hline \multirow{2}{*}{ Oral } & degree & $\mathrm{N}$ & Mean & Std. Deviation & Std. Error Mean \\
\hline Materials & Bachelor & 90 & 14.4222 & 3.68104 & .38802 \\
& Master & 29 & 16.3793 & 4.27128 & .79316 \\
\hline Dictionary & Bachelor & 90 & 18.9556 & 4.14054 & .43645 \\
& Master & 29 & 19.5862 & 4.04896 & .75187 \\
\hline Place & Bachelor & 90 & 7.1333 & 1.90917 & .20124 \\
& Master & 29 & 7.3103 & 2.37702 & .44140 \\
\hline
\end{tabular}

As can be seen in Table 7, teachers with a master's degree differed in their use of techniques from their counterparts with a bachelor's degree in only one respect, and this was their more extensive use of oral techniques ( $\mathrm{t}=2.39, \mathrm{df}=117, \mathrm{p}<.05$, effect size $=.21$, small effect). Teachers with master's degree on average made greater use of these techniques $(M=16.37)$ than teachers who held bachelor's degrees $(M=14.42)$. 
Table 7. Results of independent samples T-test comparing teachers with bachelor's and master's degrees in their use of techniques

Independent Samples Test

Levene's Test for Equality $\quad$ T-test for Equality of Means of Variances

\begin{tabular}{lllllll}
\cline { 3 - 7 } & & $\mathrm{F}$ & $\mathrm{Sig}$. & $\mathrm{t}$ & $\mathrm{df}$ & Sig. (2-tailed) \\
\hline Oral & Equal variances assumed & .89 & .34 & -2.39 & 117 & .018 \\
& Equal variances not assumed & & & -2.21 & 42.24 & .032 \\
\hline Materials & Equal variances assumed & .19 & .65 & -.71 & 117 & .47 \\
& Equal variances not assumed & & & -.72 & 48.32 & .47 \\
\hline Dictionary & Equal variances assumed & 4.09 & .04 & -.40 & 117 & .68 \\
& Equal variances not assumed & & & -.36 & 40.30 & .71 \\
\hline Place & Equal variances assumed & 1.85 & .17 & -.54 & 117 & .58 \\
& Equal variances not assumed & & & -.50 & 41.54 & .62 \\
\hline
\end{tabular}

The teachers who participated in the present study also varied in terms of age. Therefore, age could also be a potential factor influencing the use of techniques for teaching pronunciation in the classroom. In order to determine whether older teachers preferred certain techniques compared to their younger counterparts, a set of correlations were run. The results of this correlation analysis reveal that there is no significant relationship between teachers' age and the four methods of teaching pronunciation. Table 8 shows the details of the correlation analysis.

Table 8. Correlations between teacher's age and their preferred techniques of pronunciation instruction

\begin{tabular}{|c|c|c|c|c|c|c|}
\hline \multicolumn{7}{|c|}{ Correlations between age and methods of teaching pronunciation } \\
\hline & & oral & materials & dictionary & place & age \\
\hline \multirow[t]{2}{*}{ Age } & Pearson Correlation & -.015 & -.142 & -.152 & -.032 & 1 \\
\hline & Sig. (2-tailed) & .870 & .121 & .097 & .727 & \\
\hline
\end{tabular}

Apart from gender, level of education and age, the teachers who participated in this study were also compared based on their years of experience. In order to see if more experienced teachers were different in their use of pronunciation techniques in the classroom, the participants were divided into three groups: teachers with low, mid and high levels of experience. Teachers working for over 20 years in the public education system were considered to belong to the category of high experienced teachers; also, those participants teaching at public schools for 10-20 years and those having taught for less than 10 years were categorized as mid- and low-level experienced teachers. It should be noted that this classification was only done for the purposes of this study, and is not based on the official definition provided by the Ministry of Education, which states that a teacher's experience is not to be evaluated based on their years of experience, but based on their competencies and innovations in teaching (Iran Ministry of Education, 2013). A one-way ANOVA was the statistical test of choice to observe any existing difference in the use of the four techniques between the three groups. The results of this analysis can be seen in table 9 . 
Table 9. Results of the one-way ANOVA comparing techniques used by teachers in terms of their years of experience

\begin{tabular}{llllll}
\hline & Sum of Squares & df & Mean Square & F & Sig. \\
\hline Between Groups & 66.284 & 3 & 33.142 & .195 & .823 \\
Within Groups & 86.651 & 116 & 169.806 & & \\
Total & 87.935 & 119 & & & \\
\hline
\end{tabular}

The results of the ANOVA test reveal that teachers with various degrees of experience did not significantly differ from each other in the techniques that they used for teaching pronunciation in the high school classroom.

\section{Discussion}

As the mentioned findings show, Iranian English teachers use different techniques (oral repetition, using materials, using dictionary, focusing on the place of articulation, etc.) in teaching pronunciation among which oral repetition is the most common technique. Trofimovich and Gatbonton (2006) concluded repetition and focusing on form as beneficial techniques in L2 pronunciation teaching. Silveira (2002) analyzes the most used approaches for L2 teaching, especially in the area of pronunciation, and he concludes that one of the best methods applied in teaching pronunciation is "imitating a model through repetition" (p. 95). Similar to the present study, Hayati (2010) represent that to learn the sound system of a foreign language such as English, imitation is the first technique commonly used by teachers. Oral repetition makes students imitate the pronunciation modeled by the teacher. In the process of teaching pronunciation, some listening discrimination tasks are suggested in which the students are asked to listen carefully to the model pronounced by their teacher in order to distinguish similar or different sounds (Silveira, 2002). Oral interview with a number of Iranian English teachers revealed that repetition method is believed to be the simplest technique for teaching pronunciation, since students can see their teacher's movements of lips, teeth, and tongue and hear how he/she pronounces the sounds simultaneously.

Another explored factor to be taken into consideration is the role of male or female teachers in teaching pronunciation, as gender differences are beneficial in L2 acquisition (Rahimpour \& Yaghubi-Notash, 2008). According to the findings of this study, male teachers outperformed females using oral factors. Among 20 components given in the questionnaire, 8 factors extracted as oral. These factors are oral repetition, paying attention to pronunciation of sounds, corresponding L1 and L2 sounds, giving importance to correct pronunciation, practicing the sounds in peer groups, elaborating of different sounds in L1 and L2, teaching L2 sound in more simple words, and oral assessment. For both male and female teachers to be impressive in oral model, teachers are provided to have an audible voice, although sometimes teachers suffer voice problems in their own teaching, and it is obvious that voice problems affect the process of teaching. In one study done by Smith et al. (1998) on voice problems among teachers, it was concluded that female teachers showed more problems with their voce than males and these problems affect their teaching process. Since teaching oral techniques for a long time takes energy, it can possibly be said that female teachers act more cautiously than their male colleagues in these models.

Using materials, in which male teachers outperformed than females, has been indicated by 7 factors in this study. Factors arranged orderly from the most used to the least, including: listening to tape, dictation assessment, correction of badly pronounced sounds using tapes, multiple choice assessment technique, using mirrors, elaborating the sound system by using diagrams, and using pictures. Tomlinson (1998) defines materials as everything that help learners to learn a language such as textbooks, cassettes, hand-outs, etc., since materials facilitate the process of learning.

In the present study teachers are divided by their degrees into bachelors and masters. The results show that teachers with master degree performed better than the others with bachelor degree. Although Shulman (1986) shows his idea about different university degrees from the highest (doctrine) in universities to lower stages (master) in high schools all as "teacher" (p. 6), it is possible that having a higher degree helps teachers to act more perfectly in their decisions about which technique to choose in their teaching process.

In this study teachers' age indicated no significant relationship with methods of pronunciation teaching. Feldman (1983) believes that age has a weak relation to effectiveness of teaching and sometimes this relationship becomes negative. 


\section{Conclusion}

Among 20 different methods of teaching pronunciation which are used more frequently by Iranian English teachers, imitation as oral repetition has shown the first and foremost place. Using different kinds of materials such as pictures, making students use dictionaries to see the correct pronunciation, and showing the organs of articulation through pictorial diagrams are the second, third, and fourth effective factors respectively. By descriptive statistics for male and female teachers, men show a higher mean in using oral repetition and also in using instructional materials for teaching pronunciation. Those teachers with higher degrees do better in using different techniques in general and oral repetition in particular. Furthermore, teachers having a higher degree and more work experience have better understanding which method to choose for teaching pronunciation to their students which is simpler and easier. It is assumed that although frequent techniques used in our schools by male and female teachers are taken away by other teaching pronunciation techniques introduced by some researchers such as Nation and Newton, there will still remain a question to what extent these techniques are helpful in Iran's pedagogical system. Future studies may focus on the roles of these techniques in the achievement of Iranian EFL learners.

\section{References}

Breitkreutz, J. A., Derwing, T. M., \& Rossiter, M. J. (2000). Pronunciation teaching practices in Canada. TESL Canada Journal, 19(1), 51-61.

Celce-Murcia, M., Brinton, D. M., \& Goodwin, J. M. (1996). Teaching pronunciation: A reference for teachers of English to speakers of other languages. Cambridge: Cambridge University Press.

Derwing, T. M., \& Munro, M. J. (2005). Second language accent and pronunciation teaching: A research based approach. TESOL Quarterly, 39(3), 379-397. http://dx.doi.org/10.2307/3588486

Feldman, K. A. (1983). The seniority and instructional experience of college teachers as related to the evaluations they receive from their students. Research in Higher Education, 18(1), 3-124. http://dx.doi.org/10.1007/BF00992080

Gelvanovsky, G. V. (2002). Effective pronunciation teaching: Principles, factors, and teachability. In P. V. Sysoyev (Ed.), Identity, culture, and language teaching. USA: CREEES.

Hammerly, H. (1982). Contrastive phonology and error analysis. International Review of Applied Linguistics in Language Teaching, 20(1-4), 17-32. http://dx.doi.org/10.1515/iral.1982.20.1-4.17

Hayati, M. (2010). Notes on teaching English pronunciation to EFL learners: A case of Iranian high school students. English Language Teaching, 3(4), 121-126.

Hoseini Fatemi, A., \& Shahriari Ahmadi, H. (2010). To teach or not to teach: On the didactic aspect of accent training in the EFL classroom. Iranian EFL Journal, 6(3), 28-44.

Iran Ministry of Education. (2013). The comprehensive center of information of Ministry of Education. Retrieved from http://www.medu.ir/Portal/Home/Default.aspx?CategoryID=9ae1349c-4a7a-49ca-be19 -aed637f6655a

Jenkins, J. (1998). Which pronunciation norms and models for English as an international language? ELT Journal, 52(2). Oxford University Press.

Kang, O. (2009). ESL learners' attitudes toward pronunciation instruction and varieties of English. In J. Levis, \& K. LeVelle (Eds.), Proceeding of the $1^{\text {st }}$ pronunciation in second language learning and teaching conference (pp. 105-118). Iowa State University Press.

Kellerman, S. (1990). Lip service: The contribution of the visual modality to speech perception and its relevance to the teaching and testing of foreign language listening comprehension. Applied Linguistics, 11(3), 272-280. http://dx.doi.org/10.1093/applin/11.3.272

Kelly, L. G. (1969). 25 centuries of language teaching. Rowley, MA: Newbury House.

Kim, Y. H. (2009). An investigation into native and non-native teachers' judgments of oral English performance: A mixed methods approach. Language Testing, 28(2), 187-217. http://dx.doi.org/10.1177/0265532208101010

Krashen, S. D. (1982). Principals and practice in second language acquisition. Pergamon Press Inc.

Levis, J. M., \& Grant, L. (2003). Integrating pronunciation into ESL/EFL classrooms. TESOL Journal, 12(2), 13-19. 
Morley, J. (1991). The pronunciation component in teaching English to speakers of other languages. TESOL Quarterly, 25(3), 481-520. http://dx.doi.org/10.2307/3586981

Murphy, J. (2003). Pronunciation. In Practical English language teaching (pp. 111-128). Boston.

Nakatani, Y. (2002). Improving oral proficiency through strategy training (Unpublished doctoral dissertation). The University of Birmingham.

Nakatani, Y. (2005). The effects of awareness-raising training on oral communication strategy use. The Modern Language Journal, 89(1), 76-91. http://dx.doi.org/10.1111/j.0026-7902.2005.00266.x

Nakatani, Y. (2006). Developing an oral communication strategy inventory. The Modern Language Journal, 90(2), 151-168. http://dx.doi.org/10.1111/j.1540-4781.2006.00390.x

Nation, I. S. P., \& Newton, J. (2009). Teaching ESL/EFL listening and speaking. Routledge, Taylor \& Francis.

Politzer, R. L., \& McGroarty, M. (1985). An exploratory study of learning behaviors and their relationship to gains in linguistic and communicative competence. TESOL Quarterly, 19(1), 103-123. http://dx.doi.org/10.2307/3586774

Purcell, E., \& Suter, R. (1980). Predictors of pronunciation accuracy: A reexamination. Language Learning, 30(2), 271-287. http://dx.doi.org/10.1111/j.1467-1770.1980.tb00319.x

Rahimpour, M., \& Yaghubi-Notash, M. (2008). An investigation in the effect of gender on the speech of EFL learners (writers' Trans.). Study and Research of Humanistic Faculty of Esfahan University, 52(2), 111-123.

Richards, J. C., \& Renandya, W. A. (2002). Methodology in language teaching: An anthology of current practice. Section 8-Teaching pronunciation (pp. 175-177). Cambridge University Press.

Richards, J., Platt, J., \& Weber, H. (1985). Longman dictionary of applied linguistics. Longman.

Shulman, L. S. (1986). Those who understand: Knowledge growth in teaching. Educational Researcher, 15(2), 4-14. http://dx.doi.org/10.3102/0013189X015002004

Silveira, R. (2002). Pronunciation instruction classroom practice and empirical research. Linguagem \& Ensino, 5(1), 93-126.

Smith, E., Kirchner, H. L., Taylor, M., Hoffman, H., \& Lemke, J. H. (1998). Voice problems among teachers: Differences by gender and teaching characteristics. Journal of Voice, 12(3), 328-334. http://dx.doi.org/10.1016/S0892-1997(98)80022-2

Stuparyk, M. (1996). New Canadians eager to master English: Course helps Canadianize accents. The Edmonton Journal, G6.

Tomlinson, B. (1998). Materials development in language teaching. Cambridge: Cambridge University Press.

Trofimovich, P., \& Gatbonton, E. (2006). Repetition and focus on form in processing L2 Spanish words: Implications for pronunciation instruction. The Modern Language Journal, 90(4), 519-535. http://dx.doi.org/10.1111/j.1540-4781.2006.00464.x

Usher, C. L. (1995). Improving evaluability through self-evaluation. Evaluation Practice, 16(1), 55-64. http://dx.doi.org/10.1016/0886-1633(95)90007-1

Zemanova, S. (2007). Teaching English pronunciation to adult learners. Diploma thesis, University of Masaryk.

\section{Copyrights}

Copyright for this article is retained by the author(s), with first publication rights granted to the journal.

This is an open-access article distributed under the terms and conditions of the Creative Commons Attribution license (http://creativecommons.org/licenses/by/3.0/). 